\title{
POR CORREREM OS TEMPLOS NUBLADOS: UM ESTUDO SOBRE O CLERO E A CONJURAÇÃO MINEIRA*
}

\author{
André Figueiredo Rodrigues \\ Graduando Depto. de História-FFLCH/USP
}

RESUMO: O artigo aborda a posição sócio-econômica do clero e sua atuação no contexto histórico da Conjuração mineira. A partir da documentação tentaremos traçar um perfil desse clero e de alguns de seus membros, mais especificamente, os envolvidos na Conjuração.

ABSTRACT: This article discusses the clergy's social and economic positions as well as its role in the historical context of the Conjuração mineira. Based on a documentary analysis, the profile of the clergy and its members engaged in the Conjuração is outlined.

PALAVRAS-CHAVE: Clero, Conjuração mineira, Instruções, Eclesiásticos, Devassa, Dízimo.

KEYWORDS: Clergy, Conjuração mineira, Instructions, Ecclesiastics, Devassa, Tithe.

* O artigo faz parte de uma pesquisa intitulada $O$ Clero e a Conjuração Mineira (1788 - 1792) com o patrocínio da Fundação de Amparo à Pesquisa do Estado de São Paulo (FAPESP). Agradeço a amiga Rita de Cássia Sam pelas sugestões oferecidas. O título é
Assistem na Capitania de Minas Gerais muitos clérigos ociosos e inúteis que se ocupam em negociações e que escandalizam os povos com as suas licenciosas vidas e com as perturbações com que inquietam o sossego público.

João José Teixeira Coelho uma referência ao momento conturbado pelo qual passavam os membros eclesiásticos processados e julgados pela devassa. Cf. Inquirição feita ao padre José Maria Fajardo de Assis (ADIM, 1976, vol. 1, p. 268). 
A intensa religiosidade católica, o fascínio pelo ouro e o desejo de afirmação e autonomia explicam o universo mental do mineiro no século XVIII. A religiosidade portuguesa era marcada pelo apreço à pom$\mathrm{pa}^{1}$; o ouro tornou-se o sonho de cada habitante da região, e acreditou-se que sua posse proporcionaria a independência e a liberdade de cada um. Tudo em Minas Gerais foi novo, ou seja, decorreu dessa diversidade étnica, cultural e econômica. Para a primeira temos a presença marcante de portugueses, africanos e brasileiros. A influência cultural foi-nos legada por meio da junção transplantada e mesclada de crenças, idiomas, costumes, hábitos, preferências e sensibilidades de negros, indígenas e portugueses.

As relações econômicas giravam principalmente em torno da exploração e extração de ouro e pedras preciosas (diamante). O que mais nos chama atenção é o fato de que esse processo histórico da capitania mineira foi singular, não ocorrendo em nenhuma outra localidade do império colonial português na América. A característica mais importante dessa formação histórica foi a urbanização ocorrida ao longo do setecentos, resultado de uma extensa rede de centros urbanos. Adicione-se a isto, a diversificação da economia através do comércio, artesanato, serviço de auxílio, mineração, agricultura e pecuária. Somam-se a esses dados ainda o contingente populacional, a

\footnotetext{
${ }^{1}$ A pompa religiosa foi típica da Igreja da Contra-Reforma e serviu ainda de apoio suplementar ao poder monárquico em Portugal.

${ }^{2}$ A bibliografia a respeito desses assuntos é por demais extensa. Indicamos, portanto, como referências apenas alguns estudos, entre eles: FIGUEIREDO, Luciano. O Avesso da Memória: o Cotidiano e Trabalho da Mulher em Minas Gerais no Século XVIII. Rio de Janeiro, José Olympio; Brasília, Edunb, 1993; LIMA JÚNIOR, Augusto de. A Capitania de Minas Gerais. São Paulo, EDUSP; Belo Horizonte, Itatiaia, 1978. (Reconquista do Brasil,
}

estrutura administrativa introduzida e a constituição de um mercado consumidor interno ${ }^{2}$. Com o clero não será diferente, na medida em que representou um "espelho meio torto" das relações sociais, políticas e econômicas deste mundo com a metrópole.

A importância do clero como pólo sociopolítico é enorme na época colonial brasileira, principalmente em Minas. A religião para o Estado português é um norteador de normas éticas e de conduta coletiva, ou seja, as maneiras de se comportar perante o social, o político e o econômico, lembrando que a unidade religiosa era pré-condição da unidade política. Devemos advertir ainda que a idéia de legitimação do poder real, fundada nas leis divinas, tinha sua inferência na obediência dos súditos às leis humanas, emanadas do príncipe ou por ele aplicadas (WEHLING, 1986, p.173174; VASCONCELLOS, 1935, p.9-14; HESPANHA \& GOUVEIA, s.d., p.287-290). Essas idéias estão fortemente presentes nas Instruções orientadas aos governadores de capitania. E, justamente, para compreendermos esses fenômenos históricos que cercam o clero mineiro e, mais especificamente, o clero conjurado, partimos de uma documentação baseada nos

51); LUNA, Francisco Vidal \& COSTA, Iraci Del Nero da. $M i$ nas Colonial: Economia e Sociedade. São Paulo, Pioneira; FIPE, 1982; NOVAIS, Fernando A. Portugal e Brasil na Crise do Antigo Sistema Colonial (1777 - 1808). 6 a ed. São Paulo, Hucitec, 1995; PAIVA, Eduardo França. Escravos e Libertos nas Minas Gerais do Século XVIII: Estratégias de Resistência Através de Testamentos. São Paulo, Annablume, 1995; PINTO, Virgílio Noya. O Ouro Brasileiro e o Comércio Anglo-Português. São Paulo, Companhia Editora Nacional, 1979. (Brasiliana, 371); SOUZA, Laura de Mello e. Desclassificados do Ouro: a Pobreza Mineira no Século XVIII. $3^{\mathrm{a}}$ ed. Rio de Janeiro, Graal, 1990; ZEMELLA, Mafalda P. O Abastecimento da Capitania de Minas Gerais no Século XVIII. São Paulo, Hucitec; EDUSP, 1990. Além dos indicados na referência bibliográfica. 
Autos de Devassa da Inconfidência Mineira ${ }^{3}$, na Instrução para o Governo da Capitania de Minas Gerais por José João Teixeira Coelho, na Instrução para o Visconde de Barbacena Luiz Antonio Furtado de Mendonça pelo secretário da Marinha e Domínios Ultramarinos portugueses Martinho de Mello e Castro e os Autos Crimes Contra os Réus Eclesiásticos.

As informações existentes sobre o grupo eclesiástico mineiro setecentista foram-nos transmitidas por meio de documentos expedidos por instituições e órgãos representativos do poder reinol ${ }^{4}$. Entre essas certidões encontra-se a Instrução para o Governo da Capitania de Minas Gerais. Esse texto é um dos registros mais importantes para se entender o estado político, econômico, social e religioso mineiro. Os relatos iniciam-se com a descoberta do ouro em 1694 e vão até o governo de D. Antônio de Noronha (17751780). O autor viveu durante onze anos em Vila Rica, trabalhando como intendente do ouro da Casa de Fundição e servindo a quatro governadores. O que nos interessa nesse ensaio é o seu oitavo capítulo "Reflexões sobre o Estado Eclesiástico da Capitania de Minas Gerais", que perfaz um minucioso estudo sobre a conduta e a relaxação dos costumes, o comportamento desregrado e como os interesses particulares sobrepunham-se aos coletivos; tudo isso, gerado

\footnotetext{
${ }^{3}$ Autos de Devassa é a documentação oriunda dos trâmites judiciais ocorridos na capitania de Minas Gerais. Ocorreram três devassas. Duas (Minas Gerais e Rio de Janeiro) concomitantemente em franco conflito de jurisdição, versando o mesmo suposto delito, qual seja, investigar o crime de lesa-majestade de primeira cabeça. A última devassa, em nível de Alçada, tinha poderes para tudo sanar e lavrar sentença irrecorrível.

${ }^{4} \mathrm{O}$ corpo documental constitui-se de cartas de lei, alvarás, decretos, cartas régias, bandos, instruções e avisos. Essa documentação nos permite pensar a relação conflitiva existente entre a jurisdição eclesiástica e a civil.
}

a partir das descobertas auríferas, pois de todas as partes

... entraram a concorrer novos povoadores movidos pela ambição. Os frades de diversas religiões, levados pelo espírito do interesse, e não do bem das almas, acrescentaram em grande parte o número do povo: eles, como se fossem seculares, se fizeram mineiros e se ocuparam em negociações e em adquirir cabedais por meios ilícitos, sórdidos e impróprios do seu estado (COELHO, 1994, p.110).

Além disso, a política colonialista portuguesa, conforme aparece ressaltada pelo desembargador Teixeira Coelho, aflui não para a idéia de exclusão, mas sim para a idéia de limitação do contingente sacerdotal, ou seja, deveria ficar a serviço estatal e eclesiástico àqueles clérigos ligados ao seu ministério. Assim o autor se refere a temática:

Como era impossível que na Capitania de Minas deixassem de residir sacerdotes para a administração dos sacramentos e mais funções santas de religião, e por isso não podiam ser expulsos como o foram os frades (...); que se não consentissem nas Minas clérigos desnecessários, mas só aqueles que fossem precisos para o serviço das igrejas (COELHO, 1994, p.112).

Devemos ter em mente que estamos em uma área com forte presença da religiosidade popular; daí a idéia de sincronismo entre a cultura popular e a cultura erudita de tradição católica. Não obstante essas colocações, a seleção de candidatos ao sacerdócio era feita quase sem nenhum critério sobre a conduta moral do indivíduo. $\mathrm{O}$ autor continua:

Desde a nomeação do bispo de Mariana, Dom Joaquim Borges de Figueiroa, se tem conferido ordem a um grande número de sujeitos, sem necessidade e sem escolha. Tem-se visto alguns que, havendo aprendido ofícios mecânicos e servido de soldados na Tropa paga, se acham hoje feitos sacerdotes (COELHO, 1994, p.112).

A ordenação de indivíduos criminosos, segundo cartas-régias e instruções, recomendava aos bispos que não conferissem ordens eclesiásticas a delinqüen- 
tes antes de satisfazer suas penas. Houve muitos clérigos que se consagraram para fugir à justiça comum. De acordo com Teixeira Coelho, o bispo de Mariana, Inácio Corrêa de Sá, conferiu sacramentos a 84 pretendentes e, entre eles, havia um devedor da fazenda real. O português José Ribeiro Dias, culpado de ter participado do "levante das Minas" (1720), ordenouse padre para não ser preso, o que não o impediu que fosse expulso das Gerais em 1733. Outro exemplo: o capitão-mor Antônio Gonçalves, de Aiuruoca, decidiu abrir uma picada (caminho) que ia de Aiuruoca à fazenda Santa Cruz, no Rio de Janeiro. Em Minas, decorrente dos constantes e vultosos contrabandos de ouro em pó, era proibida a abertura de picadas. Com isso, o capitão violou a proibição e para não ser preso pela justiça comum, fez-se consagrar presbítero, tomando as "ordens de missa" em 1957 (COELHO, 1994, p. 113; TRINDADE, 1953, p. 56-61; BARBOSA, 1979, p. 394; VASCONCELLOS, 1935, p. 22).

O padre José da Silva e Oliveira Rolim, participante da Conjuração, é um exemplo típico de indivíduo que se ordenou para fugir da justiça. Em sua inquirição, o delator Silvério dos Reis comentou que

... o dito padre um dos cabeças do dito temerário insulto (...), tanto pela sua riqueza e abundância de bens e respeito que conserva, como por ser temerário e régulo; pois que se ordenou para se evadir às penas do crime que lhe resultou de uma morte que fez (ADIM, 1981, v.4, p.46).

Nas “Observações sobre a Inconfidência Mineira e o Direito da Coroa de Portugal sobre o Brasil" aparecem demonstrados conflitos de jurisdição, ao passo que a

... inconstância e a malícia humana têm inventado regras, não só para desobedecer temerariamente às leis, mas até para obrigar a devassidão ainda das mais necessárias e fundamentais do Estado, sem atender a que a verdadeira felicidade do mesmo Estado consiste na obediência que a elas se deve prestar e oxalá que este mal só tivera a sua origem na corrupção dos povos (ADIM, 1977, v.9, p.292)
O pensamento reinol acreditava que um bom vassalo era ser um bom católico ${ }^{5}$. A religião estatal era católica e os súditos (membros da sociedade), deviam ser católicos. Essa preocupação não condiz com a realidade porque os clérigos mineiros, ao demonstrar um comportamento contrário aos estabelecidos pelo Estado, qual seja o de acompanhar a população na sua obrigação de pagar a Sua Majestade os direitos que lhes são devidos, não estão praticando qualquer irregularidade, na medida em que a sociedade e a Igreja a que pertenciam coexistiam com esse procedimento.

Os sacerdotes seculares ${ }^{6}$, muitas vezes, com uma formação duvidosa e na maioria dos casos resultante de um trabalho doutrinal disperso e parcelar, ingressavam na carreira eclesiástica com possibilidade para uma diversidade de profissões bem além do exercício de funções clericais. Esse ingresso, como explicita Ana Mouta Faria, contribuía certamente para auferir os escrúpulos de muitos em fazer depender "a subsistência própria de obrigações e semelhante natureza, pois que a possibilidade de opção se adequavam a outras inclinações e aspirações". Entre elas, citamse o gerenciamento do patrimônio da Igreja, dos clérigos, de confrarias e de muitos leigos, administrando o aparelho burocrático das dioceses e de ordens religiosas (FARIA, 1987, p.39, 35; HESPANHA \& GOUVEIA, s.d., p.287-292). Por tudo isso, não havia qualquer controle por parte da Igreja. É dentro deste ambiente que surgem muitos párocos "ociosos e inúteis que se preocupam em negociações e que escandalizam os povos com suas licenciosas vidas" (COELHO, 1994, p.12).

\footnotetext{
5 “... esquecidos das obrigações de vassalos e de católicos” (ADIM, 1977, v.9, p. 277).

${ }^{6}$ São aqueles que não pertencem a qualquer Ordem Religiosa ou Instituição Monástica.
} 
Acima de tudo, a preocupação do Estado com esses senhores da fé referem-se à interferência destes em assuntos jurídico-econômicos da Coroa. Para compreendermos melhor esse tópico, recorremos à Instrução para o Visconde de Barbacena, na qual mostra que os clérigos não estão cumprindo com seus compromissos, ou seja, o de conduzir o povo para que atuem corretamente, ou melhor, para que direcionem a população ao cumprimento exato de sua obrigação, o correto pagamento dos impostos. O ministro Martinho de Mello e Castro comentou que os padres deviam

... ensinar aos povos os preceitos da lei que professam, pregar-lhes o evangelho, administrar-lhes o sacramentos e conduzilos com o zelo, desinteresse e regular comportamento de um bom e exemplar pastor ao gremio da igreja, de quem são filhos; os parochos de Minas Geraes, porém invertendo esta doutrina, a tem apropriado em grande parte aos seus reprovados e particulares interesses: dando occasião a repeditas (sic) e multiplicadas queixas, que desde tempos anteriores até agora tem successivamente chegado á real presença, de insuportaveis e forçadas contribuições, debaixo do pretexto de direitos parochiaes, benezes (sic), e pés de altar, com que os mesmos parochos obrigavam e obrigam aos seus fregueses a lhes contribuir (CASTRO, 1953, p.118).

As Instruções analisadas seguem uma concepção medieval, na qual o clérigo tem de rezar, o povo tem de trabalhar para poder pagar aos impostos e os nobres, administrar a justiça e a real fazenda. Ao Estado interessava muito mais o controle político-administrativo do que o controle da Igreja. O clero era freqüentemente atacado pelo governo e teve de apresentar, várias vezes, claros indícios de submissão ao poder para garantir sua sobrevivência. Verifica-se, por conseguinte, que a Igreja estava mais preocupada com o aspecto econômico do que realizar uma comparação entre a vida particular do religioso e o seu papel moral na sociedade.

O rei de Portugal detinha o direito de recolher os tributos devidos pelos súditos da Igreja conhecidos como dízimo ${ }^{7}$. A preocupação com a coleta dos dízimos era evidentemente inquietante, à proporção que a arrecadação dos quintos de ouro anuais estava em retração e a cota dizimal representava uma enorme fonte de lucro para a Coroa. De acordo com o historiador Kenneth Maxwell, temos os seguintes valores sobre a cobrança de dízimos e o recolhimento do quinto real (em arrobas):

\begin{tabular}{|c|c|c|}
\hline ANO & DíZIMOS & $\begin{array}{c}\text { ARROBAS DE } \\
\text { OURO }\end{array}$ \\
\hline 1780 & 64.968 & 65 \\
\hline 1781 & 64.968 & 72 \\
\hline 1782 & 64.968 & 65 \\
\hline 1783 & 64.968 & 62 \\
\hline 1784 & 65.368 & 58 \\
\hline 1785 & 65.368 & 54 \\
\hline 1786 & 65.368 & 49 \\
\hline 1787 & 65.368 & 43 \\
\hline 1788 & 65.368 & -- \\
\hline 1789 & 82.311 & -- \\
\hline
\end{tabular}

FONTE: Kenneth Maxwell. A Devassa da Devassa, p.281; 287-288.

É interessante notar que os dízimos eram, muitas vezes, desviados de sua finalidade (construção de templos, fornecer paramentos, pagar as côngruas aos vigários) para servirem de pagamento de salários aos governadores, aos estabelecimentos militares, judici-

${ }^{7}$ Os dízimos são a décima parte dos ganhos obtidos em qualquer atividade. Dividem-se em três tipos: reais ou prediais (devido às novidades colhidas nas propriedade rurais), mistos (provêm de animais, "caça e aves que se criam e peixes que se pescam") e pessoais (meramente industriais). Os dois primeiros eram pagos ao rei. De acordo com Dom Oscar de Oliveira, em pesquisa feita no Vaticano, não encontrou qualquer explicação que autorizasse os reis portugueses a arrecadar os dízimos na América portuguesa (OLIVEIRA, 1964, p. 59 - 64). 
ais, administrativos e fiscais. Gonzaga deixou-nos preciosos relatos de tais arbitrariedades ocorridas nas cobranças de débitos fiscais. Na sétima carta do poema satírico Cartas Chilenas, o poeta comenta essa questão:

\footnotetext{
A sábia Lei do Reino quer, e manda,

Que os nossos devedores não se prendam:

Responde agora tu, por que motivo

Concede o grande Chefe, que tu prendas

A quantos miseráveis te deverem?

Por que, meu Silverino? Porque largas,

Porque mandas presentes, mais dinheiro.

(...)

A Lei do teu Contrato não faculta,

Que possas aplicar aos teus negócios

Os públicos dinheiros. Tu com eles

Pagaste aos teus credores grandes somas:

Ordena a sábia Junta, que dês logo

Dá tua comissão estreita conta:

O Chefe não assina a Portaria,

Não quer, que se descubra a ladroeira;

Porque tu favorece ainda à custa

Dos Régios interesses, quando finge,

Que os zela muito mais, que as próprias rendas.

(GONZAGA, 1995, p.162-163)
}

$\mathrm{Na}$ Instrução para o Visconde de Barbacena aparece claramente a questão dos dízimos. $\mathrm{O}$ ministro Martinho de Mello e Castro orienta as obrigações dos paroquianos, diminuindo-as ${ }^{8}$. Essa medida procurou, também, desafogar a fazenda real que, em Minas, dispendia 200\$000 réis anuais a cada clérigo. Esse valor correspondia ao pagamento de côngruas, que era uma remuneração paga aos bispos, cônegos, vigários colados (ministros diocesanos, coadjutores) e missionários que catequizavam índios no sertão.

\footnotetext{
8 “... se reduzam estes a umas justas e moderadas prestações dos povos, com que o parocho tenham precisamente o necessario para a sua commoda e decente sustentação" (CASTRO, 1953, p. 121 - 122).
}

Foi instituída no Reino em 8 de setembro de 1632, no momento em que a Coroa passou a controlar a cobrança dos dízimos eclesiásticos. Em Minas Gerais seu aparecimento remonta ao ano de 1718, com a intenção de diminuir o valor das conhecenças (CARRATO, 1968, p.55-57; VASCONCELLOS, 1935, p.17-18).

O ministro planejava reduzir a contribuição a apenas $50 \$ 000$ réis, transferindo a diferença estipulada às paróquias mais pobres, de outras capitanias (CASTRO, 1953, p.122). O clero mineiro seria muito afetado com essa reforma e um exemplo típico de clérigo prejudicado seria Carlos Correia de Toledo (MAXWELL, 1978, p.146). O que observamos é um jogo conflitante de interesses, uma vez que a administração metropolitana visava acolher os protestos, além de procurar reduzir e até fugir do pagamento das côngruas eclesiásticas, evitando, assim, criar novas paróquias.

Com a expansão territorial verificada em Minas a partir da segunda metade do século XVIII, surgiram povoados que exigiam a assistência espiritual. Dessa forma, o bispo criava paróquias e as provia de vigários encomendados ou não colados, isto é, àqueles que não tinham direito ao recebimento de côngruas. Estes subordinavam seu sustento através da arrecadação de conhecenças ${ }^{9}$. A criação de bispados pelo Império luso, se por um lado apresentou-se como regionalista, decorrente das diferentes taxações apos-

\footnotetext{
${ }^{9}$ A conhecença era o dízimo pessoal que os fiéis eram obrigados a contribuir para a subsistência de seus pastores. Esse imposto existia na capitania desde seus primeiros tempos (final do seiscentos). Na definição de Diogo de Vasconcellos, as conhecenças eram "bilhetes de confissão" ou imposto pascal. Como todos deviam se confessar na quaresma, os padres as distribuíam. A partir de então, fazendo o recenseamento de seus paroquianos, davam esses bilhetes aos que comungavam, como se fossem "talões de recibo" (VASCONCELLOS, 1935, p. 19).
} 
tolatas cobradas ao longo do território português e um maior controle sobre as populações na América, apresentou-se, por outro, perfeitamente expansionista, com uma visão nacional. A instituição de áreas sobre o domínio eclesiástico gerava uma ampliação territorial, o que para o período colonial significava a transgressão de acordos internacionais, como o Tratado de Tordesilhas. A expansão dava-se em direção a novos espaços que se encontravam a oeste do Tratado. Como a colonização foi articulada sob o viés econômico e religioso, podemos pensar que a mesma moldou-se com o expansionismo, o que é comprovado a partir da assinatura posterior de tratados territoriais entre a Coroa portuguesa, o Papado e outras nações, principalmente a Espanha. Como exemplo, temos o Tratado de Madri (13 de janeiro de 1750) (COELHO, 1994, p.71-72; FARIA, 1987, p.42; CASTRO, 1953, p.121122; BARBOSA, 1979, p.408; VASCONCELLOS, 1935, p.19; MAXWELL, 1978, p.126; WEHLING, 1986, p.177).

A questão da cobrança das conhecenças tornouse uma das mais conflituosas entre a instituição eclesiástica e o clero mineiro. No período da Conjuração (final da década de 80), os conflitos se agudizaram devido à retração econômica gerada pela diminuição da extração aurífera.

O salário recebido pelos seculares na capitania era irrisório e mal dava para se sustentarem, muito menos para manterem um padrão adequado à função do sacerdócio, lembrando que o custo de vida nas Gerais era alto. As possibilidades de ganho em outras funções e o desestímulo com os baixos salários levavam muitos homens de Deus a partirem para rendimentos secundários e, em alguns casos, primários.

Desde a década de 60, a mineração deixou de ser a grande ocupação econômica da sociedade, transferindo-se para atividades como o comércio, atividades eclesiásticas, jurídicas, militares, de transporte, administrativas e corriqueiras (como negros de ganho). O resultado dessa mistura populacional e profissio- nal interagia com a carreira sacerdotal. Muitos padres procuravam fugir ao peso do Estado e da própria Igreja, quando havia oportunidade, por um caminho individual, incorporando-se a essas atividades.

É conhecido o envolvimento de clérigos conjurados que se dedicavam a atividades agrícolas, à extração aurífera e diamantífera, à usura e ao tráfico de escravos e diamantes. É justamente no campo econômico-financeiro que reside o problema entre a clerezia e o Padroado, ou seja, na cobrança do dízimo. Em conseqüência disso, na época da Conjuração, um dos planos e objetivos inconfidentes era a transmissão dos dízimos aos padres para que pudessem manter professores, educandários, hospitais e casas de carida$\mathrm{de}^{10}$. Além disso, as conhecenças não seriam mais cobradas aos fiéis e sim repassadas aos padres diretamente pela instituição eclesiástica, detentora desse imposto compulsório ${ }^{11}$.

Ao pensarmos na cobrança dos dízimos paroquiais praticados por indivíduos de categoria clerical, temos em mente a idéia de separação entre a Igreja e o Estado, medida esta que decretaria o fim do regime

\footnotetext{
10 “... os dízimos perceberiam os Vigários com condição de sustentarem uns tantos mestres, hospitais, e outros estabelecimentos pios" (ADIM, 1976, v.1, p. 214).

11 “... os Vigários haviam de cobrar todos os dízimos e ficarem as desobrigas de graça” (ADIM, 1976,v.1, p. 258).

${ }^{12}$ Após a Revolução Francesa de 1789, segundo Dom Oscar, foise abolindo o pagamento dos dízimos em quase todos os países. Por exemplo, na França, em 4 de agosto de 1789; em Portugal, pelo decreto de 30 de junho de 1832, o "govêrno extinguiu inteiramente os dízimos dentro do Reino, prometendo supri-los com as côngruas provenientes do erário público. Foram, de fato, estabelecidas, mas se pagaram muito magras prestações"; na Espanha, em 29 de julho de 1837, e nos países latino-americanos como a Venezuela (26 de julho de 1862), Nicarágua ( 2 de novembro de 1861) e Costa Rica (7 de outubro de 1852) foram subrogados por côngruas do erário público. No Brasil, somente no Segundo Reinado, o governo, "independentemente de qualquer
} 
existente entre o Império colonialista luso e a Igreja Católica - Padroado ${ }^{12}$.

A troca de correspondências entre São Paulo e Minas Gerais elucida a preocupação com essa cobrança e a vexação sofrida pelos povos. O apoio sacerdotal é importante, na medida em que se constata a participação de clérigos em praticamente todos os movimentos de rebelião existentes ao longo dos séculos XVIII e XIX. Portanto, uma das medidas deveria versar sobre essa realidade. Basílio de Brito Malheiro do Lago conta-nos, em sua carta-denúncia, que ouviu na Estalagem das Cabeças uma conversa entre o mulato Crispiniano da Luz Soares e o major do regimento dos pardos do Tijuco, Raimundo Correia Lobo, que alguém de Vila Rica tinha escrito a São Paulo para que "lá se levantassem e não pagassem os dízimos" (ADIM, 1976, v.1, p.98-99). A idéia parece bem estruturada, já que, por exemplo, em São Paulo (Taubaté), o padre Carlos Correia de Toledo tinha parentes e ligações, como muitos outros conjurados, com pessoas de cargos importantes nessa capitania.

Em uma sociedade de escassa alfabetização, os senhores de Deus detinham todas as funções relacionadas ao intelectual. Intérpretes da palavra divina, os sacerdotes eram também filósofos, poetas, historiadores e professores. Não se pode esquecer de que era por meio desses funcionários públicos que girava a vida administrativa colonial e qualquer tentativa de autonomia em relação ao Estado, era duramente reprimida. O clero estava presente na vida e na morte das pessoas, nos episódios de nascimento, casamento e morte. Todos esses registros eram um hábito rotineiro, mas precioso. O domínio do número signifi-

combinação com a S. Sé, foi deixando de cobrar em muitas Províncias os dízimos que devia arrecadar". Contudo, o Estado pagava valores irrisórios como côngruas ao clero. O pagamento de dízimos só desapareceu do cenário nacional com a proclamação da República (OLIVEIRA, 1964, p. 31 - 33). cava o domínio do indivíduo. Então, controlar a Igreja era fundamental para o Estado regular a pessoa (quem devia pagar os impostos). Ainda mais, o controle das práticas religiosas ia mais longe. Ao lado dos registros de batismo e casamento, incluíam-se as desobrigas. Na época da Páscoa, os fiéis estavam sujeitos aos sacramentos da penitência, confissão e depois, de terem feito fé na transubstanciação eucarística, receberiam a comunhão. Em todos os momentos da vida litúrgica do indivíduo existia o controle, que se fechava com as visitas pastorais.

O domínio do poder reinol sobre as pessoas deuse, por isso, em todas as esferas direcionais do pensamento. Assim, a cultura eclesiástica era geradora de uma mentalidade de fundo capaz de ser estrutura de recepção de atitudes e modos de agir e pensar bem distintos daqueles que geravam as formas de religião.

Com relação à temática clerical exposta até o momento, há necessidade de um esclarecimento para não cometermos uma injustiça. Os procedimentos analisados e citados leva-nos a pensar na existência, quase generalizada, de maus padres, o que não é verdade. Se num primeiro momento, início da colonização em território mineiro, tivemos eclesiásticos aventureiros interessados em minerar como se fossem laicos, ou melhor, esquecendo-se de sua função sacerdotal, tivemos, por outro, párocos e missionários que zelaram pela religião católica, levando conforto espiritual onde se fixassem os mineiros. Raimundo Trindade deixou-nos relatos de presbíteros que cometeram desregramentos mas, também, relaciona um número avultado de sacerdotes que se distinguiram pela sua humildade e suas virtudes.

Mencionamos uma série de características e conflitos existentes entre a instituição eclesiástica e o Estado metropolitano com a intenção de demonstrarmos que os clérigos processados pela Conjuração não estiveram alheios aos acontecimentos que se processaram a partir da segunda metade do setecentos, já que faziam parte dele. O contexto colonial não os fazia 
agir diferente. A atuação dos padres conjurados deuse de forma ativa, pois possuíam uma mentalidade revolucionária, graças ao fato de viverem em colônia.

\section{Clero Conjurado}

Dos cinco eclesiásticos julgados e processados como participantes da Conjuração mineira, apenas um exercia exclusivamente o sacerdócio ${ }^{13}$.

O clero conjurado contava com capelães, garimpeiros, párocos, fazendeiros, contrabandistas, administradores de créditos e um cônego; todos, membros das famílias mais importantes da capitania. Apesar de seu estado de eclesiásticos, esses homens mantinham atividades seculares importantes, quais sejam, a de manter assegurada a cobrança dos dízimos. Todos eram homens de vasta cultura e de forte poder político. O engajamento de tais sacerdotes no movimento, através de seus procedimentos e pensamentos, é o que procuraremos demonstrar daqui por diante.

Compreender o pensamento dos clérigos inconfidentes é estudar a influência da Ilustração em terra "tupiniquim”. Os princípios filosóficos e políticos ilustrados que se difundiram nas Minas setecentistas versavam principalmente sobre a razão. Segundo os pensadores iluministas, por meio da razão atingimos os conhecimentos necessários para alcançarmos as leis naturais que regem a sociedade. Essas concepções foram transmitidas por Voltaire, Mably, Locke, Robertson, Rousseau, Montesquieu, Condillac, cujos trabalhos circulavam entre os letrados. Tem-se, também, a propagação de ideais da Encyclopédie.

Nas inquirições prestadas à devassa, muitos inconfidentes afirmaram a grande erudição e "luzes" de per-

${ }^{13}$ Os clérigos processados são José da Silva e Oliveira Rolim, Carlos Correia de Toledo e Melo, José Lopes de Oliveira, Manuel Rodrigues da Costa e Luís Vieira da Silva, este o único que exercia restritivamente os sagrados sacramentos. sonagens como Cláudio Manoel da Costa, Alvarenga Peixoto, Tomás Antônio Gonzaga e, o mais importante, a dos réus eclesiásticos, tidos como líderes ${ }^{14}$ intelectuais do movimento. Portanto, é através dessas personalidades que encontraremos referência ao Iluminismo. O representante típico das influências francesas na região das Gerais foi o cônego Luís Vieira da Silva, a quem foi dedicada a obra $O$ Diabo na Livraria do Cônego, de Eduardo Frieiro. A melhor referência bibliográfica, segundo o pesquisador, encontra-se na relação de livros que lhe foram sequiestrados pela devassa - sua biblioteca contava com aproximadamente 800 volumes ( 270 títulos). O melhor de sua livraria não está na quantidade, mas sim na qualidade das obras (FRIEIRO, 1981, p.24).

O cônego Vieira era, para seu tempo, "um sábio autêntico" (SALLES, 1982, p.151). Ao lado do padre Carlos Correia de Toledo, era um dos enciclopedistas radicais e entusiasta da revolução americana cujo pensamento político não era segredo. Segundo Francisco Antônio de Oliveira Lopes, o cônego foi quem tramara inicialmente a idéia de se formar uma república na capitania por volta de $1780-1781^{15}$. Em sua inquirição à devassa, Luís Vieira comentou que a representação de uma república partiu de Tiradentes, que a armou desde o governo de Luís da Cunha Meneses ${ }^{16}$.

\footnotetext{
${ }^{14}$ Segundo Waldemar de Almeida, a palavra líder era inexistente nessa época, sendo incorporada mais tarde do inglês (BARBOSA, 1979, p. 431).

15 “... Cônego Luís Vieira, (...) havia oito anos que tinha botado as suas medidas para reger a mesma república livre e independente; o que tudo ouviu ele, Respondente, da boca do mesmo Vigário" (ADIM, 1978, v.2, p. 65).

16 “... ainda no tempo em que governava esta Capitania o Exmo. Sr. Luís da Cunha Meneses, ouvira dizer a várias pessoas que vinham do Rio de Janeiro (...) que um alferes, por alcunha o Tiradentes, andava na dita cidade convocando gente para um levante" (ADIM, 1978, v.2, p. 146)
} 
Ao longo do processo fica transparente o entusiasmo do cônego pelos acontecimentos ocorridos na América do Norte (leia-se 13 colônias inglesas), sobre os quais falava sem prudência. Basílio de Brito Malheiro do Lago após conversar com o dito clérigo, relatou-nos:

... este não encobre a paixão que tem de ver o Brasil feito uma república; abonou o Tiradentes de um homem animoso e que, se houvesse muitos como ele, que o Brasil era uma república florescente; e que um príncipe europeu não podia ter nada com a América que é um país livre; e que El-Rei de Portugal nada gastou nesta conquista, que os nacionais já a tiraram dos holandeses, fazendo a guerra à sua custa sem El-Rei contribuir com dinheiro algum para ela; depois disto, os franceses tomaram o Rio de Janeiro, que os habitadores da cidade lha compraram com o seu dinheiro; e ultimamente concluiu que esta terra não pode estar muito tempo sujeita a El-Rei de Portugal, porque os nacionais dela querem também fazer corpo da república; e outras coisas semelhantes que todas se encaminham ao fim da liberdade (ADIM, 1976, v.1, p.102).

As palavras atribuídas ao cônego da Sé de Mariana apresentam-no como uma figura contraditória. Sua vida é a própria expressão da contradição do sistema, pois nela fica demonstrado os impasses de nossa realidade social e política vigentes.

O cônego, juntamente com outros conjurados (Gonzaga e Cláudio Manoel, principalmente), reuniase para discutir assuntos diversos ligados a uma dimensão crítica da tradição racional, recebida do Iluminismo francês, a fim de expor as arbitrariedades e algumas injustiças intrínsecas ao estatuto colonial ${ }^{17}$. Nessas reuniões sobre o pretexto de bajular o

\footnotetext{
${ }^{17}$ As injustiças cometidas nas Gerais estão registradas nas Cartas Chilenas. As sátiras às circunstâncias da gestão política de Minésio, ou melhor, o governador Luís da Cunha Meneses, aparecem metaforizados através de atos e práticas de sua administração como: suborno, ineficiência da justiça, corrupção, usura, proteção ao contrabando, irregularidade na administração dos contratos e atos de irreligiosidade.
}

governo reinol, exerciam-se atividades subversivas, promovendo discussões dos ideais franceses e dos acontecimentos que ocorriam na América inglesa. Dois livros particularmente teriam uma repercussão nesse processo, o do abade Raynal Histoire Philosophique et Politique des Établissements et du Commerce des Européens dans les Deux Index e Recueil des Loix Constitutives des Colonies Angloises, Confédérées sous la Dénomination d'États-Unis de l'AmériqueSeptentrionale. Foram as únicas obras citadas nominalmente pelos conjurados. As primeiras acusações sobre a mentalidade de Vieira partem do princípio de grande "sabedor e conhecedor" da independência norte-americana (ADIM, 1978, v.2, p.150).

Esses textos agrupam os dois grandes elementos conscientizadores do movimento conjurado, quais sejam, a questão da contraposição metrópole versus colônia e o discurso das leis e direitos de uma nação livre e independente. Por isso, no trecho citado inicialmente, percebemos influências de Raynal - direito à rebelião popular:

Se os povos são felizes sob a forma de seu governo, eles o conservarão. Se são infelizes, não serão as vossas opiniões nem as minhas - será a impossibilidade de sofrer mais e por mais tempo que irá determiná-lo a mudá-las, movimento salutar que o opressor chamará de revolta, ainda que não seja mais que o exercício legítimo de um direito inalienável e natural do homem que se oprime, e mesmo do homem que não é oprimido" (RAYNAL, 1993, p.75).

A autoridade de uma nação sobre uma outra só pode ser fundada sobre a conquista, o consentimento geral, em condições propostas e aceitas. A conquista não vincula mais que o roubo. $\mathrm{O}$ consentimento dos ancestrais não pode obrigar os descendentes. E não há condição que não seja exclusiva do sacrifício da liberdade. A liberdade não se troca por nada, porque nada tem um preço que lhe seja compatível" (RAYNAL, 1993, p.78).

As exposições de Raynal permite-nos questionar a situação em que viviam. Então, rebelar-se é tãosomente exercer um direito próprio, ainda mais que Minas Gerais vivia em constante opressão, traspas- 
sada pelos atos de Luís da Cunha Meneses e do Visconde de Barbacena. Em uma reunião na casa do tenente-coronel Francisco de Paula Freire Andrade, na qual estavam presentes Tiradentes, Alvarenga Peixoto e os padres Toledo e Rolim, esses inconfidentes exacerbaram as visões do abade como um escritor de "grandes vistas; porque prognosticou o levantamento da América Setentrional, e que a capitania de Minas Gerais com o lançamento do tributo da derrama, estaria agora nas mesmas circunstâncias" (ADIM, 1982, v.5, p.172). Assim, os acontecimentos ocorridos com os americanos do norte serviriam de exemplo para as possíveis convicções de autonomia que ali se pensava.

O plano elaborado por Vieira ${ }^{18}$ necessitava de um fato capaz de abalar a população. Esse estopim seria a decretação da derrama ${ }^{19}$ - "elemento desencadeador" e legitimador do processo (SANTOS, 1966, p.167). Para ludibriar o inquiridor sobre seu real envolvimento, o cônego contradiz a importância de tal artifício (derrama), afirmando que a mesma havia sido perdida $^{20}$. Além de utilizar tal assunto, expõe uma hipótese sobre as condições que não tornariam executáveis um movimento de libertação em território mineiro.

\footnotetext{
18 “... Vieira (...) tinha feito um papel em que mostrava a segurança deste país, e o modo por que se devia fazer a rebelião" (ADIM, 1981, v.4, p. 146).

19 “... no plano estabelecia o dito cônego que se devia esperar uma ocasião em que o povo estivesse desgostoso; e que depois se deviam tomar os quintos e que, agora se tratava de lançar a derrama, contou a ele, testemunha, Francisco Antônio de Oliveira Lopes que se tinha justo fazer o rompimento, avisando-se a todos para se ajuntarem com a senha de dizerem - tal dia é o batizado - com cujo aviso juntariam todos" (ADIM, 1981, v.4, 147).

20 “... pela Carta Circular a todas as Câmaras, do Ilmo. e Exmo. Visconde de Barbacena, em que lhes assegurava o não lançar-se sem se dar conta a S. Majestade” (ADIM, 1982, v.5, p. 247)
}

Sabe que na feliz aclamação de El-Rei D. João o quarto, sendo uma causa tão justa, e tanto da vontade dos povos, perguntou, segundo a sua lembrança, D. João da Costa, quais eram os generais, as armas, as alianças, os soldados, que tinham prontos para se levantarem contra as armas de Castela, e que isto foi bastante para se suspender a ação por oito dias, e talvez se não executasse, se nisso não tivesse o maior perigo; e como poderia pensar que tivesse feito a sublevação de Minas falta de tudo o necessário" (ADIM, 1982, v.5, p.248)

O conteúdo implícito dessa narração, feita por intermédio de uma semelhança entre a Conjuração mineira e a Restauração portuguesa de 1640, permite-nos pensar, como elucida Luiz Carlos Villalta, numa comparação entre ambos, colocando-os num mesmo patamar. Por conseguinte, se o movimento pela Restauração portuguesa foi um movimento "justo" e da "vontade dos povos", a conjura, estando equiparada a ela, também o foi. Se para o cônego a Inconfidência "equipara-se à Restauração, logo era também, (...) uma causa justa, da vontade dos povos, enfim, uma sedição legítima!!" (VILLALTA, 19951996, p.17).

Ao propor um movimento legítimo nas Minas, o cônego esteve imbuído do filosofismo ilustrado. O mais importante é que considera um levante contra o monarca, algo legítimo, da "vontade dos povos". Ao negar o princípio legitimador do poder régio, realiza uma crítica ao absolutismo, tão presente em filósofos como Locke, Rousseau e Voltaire. Como ávido leitor das filosofias revolucionárias setecentista, esteve a par das idéias de igualdade social, direito à liberdade e garantia do uso e desfrute da terra pelos colonos. Mas, acima de tudo, os princípios norteadores de seu filosofismo vieram do abade Raynal.

Além de Vieira, o padre Toledo era um grande conhecedor da filosofia de Raynal. Esse vigário representava um elemento de ligação entre os intelectuais e os revolucionários mais exacerbados, uma vez que não o eximimos do grupo dos ideólogos responsáveis pela confecção dos regimentos jurídicos. Foi, tam- 
bém, um ingressante do grupo ativista, que contava ainda com Tiradentes, Rolim, Alvarenga (outro elemento de ligação) e Paula Freire (SANTOS, 1966, p.171; SANTOS, 1927, p.114-116; MAXWELL, 1978, p. 150-151).

$\mathrm{O}$ vigário Carlos Correia foi o mais radical dos conjurados. Era muito ambicioso e o sacerdócio, uma atividade minoritária em sua vida. Era também devedor da fazenda real e conjurar-se seria um meio de livrar-se das suas dívidas.

Ao lado de Tiradentes, ao nosso entender, foi um dos grandes propagadores dos ideais inconfidentes espalhando-os pelas estradas, estalagens, fazendas, reuniões em casas de amigos e conversações ao ar livre. $\mathrm{Na}$ arregimentação de pessoal, as pessoas doutrinadas por Tiradentes foram condenadas por não terem delatado o movimento, ao passo que os indivíduos aliciados por Toledo tornaram-se delatores como Silvério dos Reis (ADIM, 1981, v.4, p.47), Inácio Pamplona (ADIM, 1976, v.1, p.193), Francisco de Paula Freire Andrade (ADIM, 1976, v.1, p.117) e Domingos de Abreu Vieira (ADIM, 1976, v.1, p.123). Tiradentes falou ao padre Manuel Rodrigues da Costa que foi condenado por não ter denunciado o movimento. Este, por sua vez, comunicou os acontecimentos a um outro clérigo envolvido e processado pela devassa como conhecedor de detalhes e conversações que manteve com os conjurados, José Lopes de Oliveira.

Ao analisamos os círculos de amizades existentes entre os eclesiásticos, deparamo-nos com a formação de dois grupos distintos. O primeiro, rotulamos como "campesinos", formado por Manuel Rodrigues da Costa e José Lopes de Oliveira. Proprietários rurais que exerciam os sacramentos em suas fazendas, comprometeram-se como conhecedores dos detalhes conjurados. O segundo era constituído pelo cônego Vieira e os padres Toledo e Rolim, que chamamos de "citadinos" e exerciam os sagrados sacramentos em paróquias localizadas nos centros urbanos de Mariana, São José e São João del-Rei.
A relação de José Lopes com a Inconfidência deve-se ao grau de parentesco com os conjurados José Aires Gomes (primo), padre Francisco Vidal de Barbosa Laje (primo) e Francisco Antônio de Oliveira Lopes (irmão). Envolveu-se em conversações com os padres Toledo e Manuel Rodrigues, seu irmão, seu primo Barbosa Laje e o delator Joaquim Silvério dos Reis. Este declarou a erudição do pároco afirmando ser de "muito conceito e dotado de grandes luzes" (ADIM, 1981, v.3, p.428-429). Seus depoimentos foram arrasadores para a conjura, revelando detalhes e os pedidos de apoio externo (ADIM, 1982, v.5, p.379-383).

Manuel Rodrigues morava em uma hospedaria situada no Caminho Novo, ponto de encontro de viajantes com destino ao Rio de Janeiro. Em uma de suas andanças por aquela localidade, Tiradentes, em setembro de 1788, expôs ao clérigo os planos do movimento inconfidente (ADIM, 1976, v.1, p.200-201). Seu envolvimento deu-se de forma comedida: sentiuse atraído pela idéia, transmitindo-a. O mestre de campo Inácio Correia Pamplona, em sua carta-denúncia, relatou uma dessas tentativas de propagação do ideário conjurado:

... havia passado para o Rio um furriel (...); e que, de Vila Rica, passara um padre (Manoel Rodrigues), que ia para a Borda do Campo, que largamente falava no levante e que dormira no Rancho das Lavrinhas do Lourenço, que também este do Rancho assim o publicava (ADIM, 1976, v.1, p.110).

Esse sacerdote foi muito mais religioso do que laico. As passagens de sua vida revelam, ao lado de uma personalidade ativa no desejo de mudanças, "um lado espiritual nunca desleixado. Parece ter sido de mentalidade mais tradicional e de espírito mais disciplinado". Cumpria suas funções religiosas, quais sejam, as visitas pastorais nas freguesias de Simão Pereira e Engenho do Mato, para ministrar a Crisma. Incitava o povo ao cumprimento de hábitos clericais, como zelar pela Igreja. Como deputado na Constituinte 
de 1823 fez um "discurso encarecendo a importância da fidelidade à religião" (JARDIM, 1989, p. 301-302).

Consideramos o padre Toledo como um elemento de ligação entre os dois grupos ("citadinos" e "campesinos"). Como Rodrigues da Costa, Toledo (pelo que podemos compreender do seqüestro feito às suas obras) possuía uma formação mais adaptada à ortodoxia católica. Enquanto Rolim prestava-se mais ao heterodoxismo, e era o mais rico dos conjurados, com negócios em Minas, Rio e Bahia ${ }^{21}$. Foi expulso, juntamente com o seu irmão Alberto da Silva (SANTOS, 1976, p.185), do Distrito Diamantino acusados de irregularidades no tráfico de escravos e na extração de ouro e diamantes. Tido como contrabandista e traficante, fugiu para a Bahia, onde permaneceu até seu regresso as Gerais, em 1787.

Com a extinção dos contratos individuais para a extração aurífera e diamantífera na região do Tijuco (comarca do Serro Frio), a família Rolim foi uma das mais prejudicadas e, a partir de então, passou a desenvolver um certo rancor perante a administração portuguesa na capitania. De acordo com Soter Couto era "a alma do garimpeiro sofredor" (COUTO, 1963, p. 326). Logo, apoiava a instauração de uma república mais por conveniência pessoal do que por qualquer outro motivo. Estava insatisfeito com a realidade local e, com a vitória, a legislação diamantífera tijuquense seria extinta, possibilitando a qualquer pessoa explorá-la ${ }^{22}$, preconizando assim o livre comércio de ouro e diaman-

\footnotetext{
${ }^{21}$ Márcio Jardim aponta por meio dos Autos a avaliação de aproximadamente 2:300\$000 réis em créditos de terceiros e mais de um a dois contos em bens móveis, totalizando a quantia estimada em cinco contos de réis, não devendo qualquer soma em dinheiro à Coroa. Esse valor eqüivaleria a uma casa paroquial - cerca de 1:000\$000 réis -, calculado trinta anos mais tarde (JARDIM, 1989 , p. 297) e a 20 escravos com habilidades caseiras, valendo-se da quantia média de $200 \$ 000$ réis para cada. 22 “... os diamantes seriam livres” (ADIM, 1981, v.4, p. 146).
}

tes. Foi considerado pela devassa mais importante que Tiradentes, por tratar-se de uma pessoa de grande influência na comarca - região muito lucrativa para a Coroa. Dentro do projeto conjurado ficou encarregado de fornecer duzentos homens e ajudar no custeio da pólvora e da munição necessária ao levante.

As relações entre o mundo sacro e o profano aparecem no estudo das condutas morais de tais sacerdotes. Como afirmamos inicialmente, não estão em contradição com a sociedade em que vivem; pelo contrário, o mundo religioso do qual fazem parte coexiste com tal comportamento. Isso porque, em muitos casos, esses padres estão em íntima comunhão com seus fiéis, sofrendo os mesmos dissabores, as mesmas dificuldades, resolvendo questões domésticas, tomando parte ativa da vida da população. Talvez aí esteja a explicação para os "paroquianos não diminuírem o respeito de lhe tributavam", apesar de alguns terem famílias (BARBOSA, 1979, p.413).

O cônego marianense Luís Vieira da Silva tinha uma filha chamada Joaquina Angélica da Silva ${ }^{23}$. Não encontramos referência a possíveis filhos do vigário Carlos Correia de Toledo, somente indicações sobre sua conduta profana frente as mulheres. No batizado de dois filhos de Alvarenga Peixoto, realizado em São João del-Rei, após as comemorações, "cada um (inclui-se Toledo) saiu com uma mulher pelo braço pela rua afora", como afirma o tenente-coronel José Franco de Carvalho (ADIM, 1976, v.1, p.266). O padre José Lopes de Oliveira era casado com sua irmã Ana Quitéria (ADIM, 1978, v.2, p.469). José da Silva e Oliveira Rolim relacionava-se com sua sobrinha

\footnotetext{
${ }^{23}$ De acordo com Tarquínio José Barboza de Oliveira, a filha do cônego teria nascido por volta de 1765 em Mariana. Casou-se por volta de 1783 com o cirurgião Francisco José de Castro, ausente em Portugal ou Angola. Era assistida em Vila Rica na casa de um cunhado (ADIM, 1981, v.3, p. 17; 348).
} 
putativa Quitéria Rita (filha da Chica da Silva), com a qual teve cinco filhos (ADIM, 1981, v.5, p.349; MAXWELL, 1978, p.160). O comportamento libidinoso deste eclesiástico fica demonstrado na inquirição de Joaquim Silvério dos Reis. Segundo ele, o dito padre "deflorou uma irmã do Ten. Cel. Simão Pires Sardinha, (...) e, casando-a com um homem branco, quis depois do casamento continuar com ela a mesma desordem" (ADIM, 1981, v.4, p.46). Para explicar a fuga que o padre cometeu ao ser denunciado à devassa, o advogado José de Oliveira Fagundes recorreu ao depoimento de João Francisco das Chagas. Esse réu afirmou que o clérigo estava "homiziado" por uma "querela de adultério" que havia praticado. A defesa praticada pelo advogado procurou eximir o dito padre da acusação de que não havia "indícios algum no processo a este respeito”. É por demais suspeita a atitude do bacharel ao recorrer a esse pequeno acontecimento dentro do corpo processual da devassa (ADIM, 1982, v.7, p.188).

Os réus eclesiásticos foram julgados junto aos demais e processados em separado por determinação da carta-régia de 17 de julho de 1790, segundo a qual deveriam ser enviados a Lisboa para receberem sentença ${ }^{24}$. Até a data de 20 de abril de 1792, guardou-se segredo de outra carta-régia (15 de outubro de 1790), que determinava que os condenados fossem agraciados com a clemência real - comutação das penas em degredo -, excluindo-se os clérigos e Tiradentes. As penas dos réus sacerdotes seriam proferidas pela rainha D. Maria I que enlouquecera. Não existindo a sentença condenatória contra tais padres, o regente $\mathrm{D}$. João VI determinou que se fizesse silêncio perpétuo

\footnotetext{
24 “Quanto aos réus eclesiásticos, que sejam remetidos a esta Corte debaixo de segura prisão, com a sentença contra eles proferida, para à vista dela Eu determinar o que melhor me parecer" (ADIM, 1982, v.7, p. 269).
}

sobre os condenados, ficando esquecidos nos conventos lisboetas.

O destino dos presbíteros foi mais duro que o dos demais - com exceção de Tiradentes, enforcado em 21 de abril de 1792. Em conseqüência de não serem condenados nem libertados, sofreram, segundo Tarqüínio, "pior sorte que os degredados: 4 anos de prisão em São Julião da Barra e mais 5 ou 6 anos de reclusão em mosteiros continuando neles até 1804, embora já livres, quando se lhes permitiu voltar ao Brasil" (ADIM, 1977, v.8, p.324).

Quanto à clemência, o exercício do perdão estava associado à legitimação do poder régio, visto que a Rainha deveria fazer-se amar e não temer. O segredo da eficiência do sistema penal estava na "inconseqüência" de "ameaçar e não cumprir". Melhor ainda, era fazer-se temer, ameaçando, do que se fazer amar, não cumprindo. Para que esse duplo efeito se produza, António Manoel Hespanha relata que "é preciso que a ameaça se mantenha e que a sua não concretização resulte da apreciação concreta e particular de cada caso, da benevolência e compaixão suscitadas ao aplicar a norma geral a uma pessoa particular" (HESPANHA, s.d., p.247; 244; 249), como foi o caso do alferes Tiradentes. A Rainha apresentou-se como uma mãe a seus filhos (súditos), legitimando ideológica e simbologicamente seu poder sobre os indivíduos, concedendo-lhes a graça. O jurista Baptista Fragoso em Regimen Republicae Christianae (1641) relatou que "não é conveniente nem que o príncipe puna sempre, nem que sempre ignore; na verdade, a função do rei é punir freqüentemente, mas ignorar ainda mais; misturar a clemência e a severidade é mais belo" (HESPANHA, s.d., p.266).

Dos cinco religiosos processados, três foram condenados à morte (Toledo, Rolim e José Lopes) e os demais a degredo perpétuo (Vieira e Manuel Rodrigues). Foram impostas aos quatro primeiros uma pena complementar, o confisco total de seus bens, e, ao último, o confisco de metade ${ }^{25}$. Tarquíínio alertou-nos que se a 
carta de clemência fosse aplicada "os três primeiros sofreriam degredo perpétuo e os dois últimos por dez anos talvez". O único beneficiado seria o padre Rolim, já que "ao invés de degredo perpétuo, cumpriu quatro anos de prisão comum e cinco de reclusão em mosteiro". A falta de sentença contra eles, motivado pelo desaparecimento dos papéis pelo ministro Martinho de Melo e Castro, deu origem à "esdrúxula situação de se não poder converter o seqüestro (mera medida acauteladora) em confisco (pena de perdimento dos bens em favor da Coroa)". Como não houve a excomunhão desses sacerdotes, por conseguinte os bens eclesiásticos tornaram-se intocáveis (ADIM, 1977, v.8, p.324325; 1977, v.9, p.334).

De todos os personagens envolvidos na Conjuração, o padre Manuel Rodrigues da Costa foi o único que conseguiu colocar em prática pelo menos um dos planos inconfidentes: a implantação de manufaturas. Regressando ao Brasil em 1804, fixou-se novamente em sua fazenda (ADIM, 1977, v.8, p.376). Preocupado com o engrandecimento da pátria, procurou estudar diversas indústrias em Lisboa enquanto este-

\footnotetext{
25 "Por tanto condemnão os Reos Carlos Correa de Toledo, Jozé da Silva de Oliveira Rolim como Chefes da Conjuração, e o Reo Jozé Lopes de Oliveira como sabedor e consentidor della a que com baraço e pregão sejam conduzidos pellas ruas publicas ao lugar da forca e nella morrão morte natural para sempre e os condemnão outro sim nas mais penas estabelecidas por direito nos crimes de leza Magestade de primeira cabeça infamia e perdimento de todos os seos bens para o Fisco e Camera Real; e ao Reo Luis Vieira da Silva condemnão em degredo, por toda a vida para a ilha de S. Tomé, e no perdimento de seos bens para o Fisco e Camera Real; e ao Reo Manoel Rodrigues da Costa condemnão em degredo por toda a vida para a Ilha do Principe, e no perdimento de ametade dos seos bens para o Fisco e Camera Real; e se estes dois ultimos Reos tornarem a entrar neste Estado do Brazil morrerão na forca morte natural para sempre (...) Rio 18 de Abril de 1792" (ANNO, 1952, p. 101).
}

ve preso, especialmente a de tecidos e a fabricação de vinhos. Isso demonstra que seu encerramento não foi tão severo assim. Sendo um homem empreendedor, instalou em sua propriedade uma pequena fábrica de tecidos de lã para confeccionar uniformes militares e estabeleceu plantações de vinhas e oliveiras (ADIM, 1981, v.4, p. 236-237; SANTOS, 1927, p. 542-543).

Em suma, quando pensamos no clero, devemos ter em mente as diversidades próprias à capitania mineira, assim como a formação de cada um de seus membros. Se por um lado o clero se via preso às determinações próprias à sua condição - orar, celebrar missas, confessar fiéis etc. -, por outro acabava-se deixando influir pelas ascendências do mundo laico. Estavam sempre em contato com tropeiros, comerciantes e intelectuais ilustrados, muitos dos quais reprodutores das idéias francesas e norte-americanas.

O envolvimento de senhores da fé na conjura foi o estopim de um processo desencadeador de mudanças adquiridos com a tomada de consciência de sua condição de colonos. Pelo menos para os mais exaltados espiritualmente como Tiradentes, padres Rolim e Toledo, o movimento foi uma tentativa de reorganização das relações existentes entre a oligarquia mineira e a política colonialista portuguesa na região, como Kenneth Maxwell apresenta em sua obra. O clero, como parte direta da relação entre estes dois pólos, não poderia ficar de fora. Não devemos observar interesses estritamente laicos, como as Instruções bem colocaram ao relatar a vida de clérigos "ociosos e inúteis que se ocupam em negociações e que escandalizam os povos" (COELHO, 1994, p.12).

A insubordinação política ao Império luso levouos a ser considerados mentores do motim. Não porque o queriam, mas porque, acima de tudo, tinham sido discriminados pelos inquiridores como aconteceu com o alferes Tiradentes. Portanto, o início de uma mentalidade revolucionária forjou-se por meio da opressão. As tentativas de separação entre a Igreja 
e o Estado viram-se concretizadas somente com a República. Mas, em 1808, as relações entre a metrópole e a colônia tornaram-se irremediavelmente alteradas com a vinda da família Real para a América portuguesa.

Como expressa o poeta na terceira lira da primeira parte de Marília de Dirceu, o homem orienta suas ações pela razão. A razão de tais clérigos talvez se explique pelo fato de viverem em colônia, como fizeram os envolvidos na Inconfidência baiana:
"De amar, minha Marília, a formosura Não se podem livrar humanos peitos. Adoram os Heróis; e os mesmos brutos Aos grilhões de Cupido estão sujeitos. Quem, Marília, despreza uma beleza,

A luz da razão precisa;

E se tem discurso, pisa

A Lei, que lhe ditou a Natureza".

(GONZAGA, s.d., p.16)

\section{Bibliografia}

(ADIM). AUTOS DE DEVASSA DA INCONFIDENNCIA MINEIRA. $2^{\text {a }}$ edição. Brasília, Câmara dos Deputados; Belo Horizonte, Governo do Estado de Minas Gerais, 1976-1983. 10 volumes.

"ANNO de 1791 / Autos Crimes / Juízo da Comissão / Contra os Reos Eclesiásticos / da Conjuração, Formada em Minas / Gerais". Anuário do Museu da Inconfidência, 1, 1952, p.71-101.

BARBOSA, Waldemar de Almeida. História de Minas. Volume 2: Formação Histórica. Belo Horizonte, Editora Comunicação, 1979.

BOSCHI, Caio César. "O Clero e a Inconfidência". IX Anuário do Museu da Inconfidência, 1993, p.111-120.

BOSCHI, Caio César. Os Leigos e o Poder. Irmandades Leigas e Política Colonizadora em Minas Gerais. São Paulo, Ática, 1986. (Ensaios, 116).

CARRATO, José Ferreira. Igreja, Iluminismo e Escolas Mineiras Coloniais. São Paulo, Companhia Editora Nacional; EDUSP, 1968. (Brasiliana, 334).

CARVALHO, José Geraldo Vidigal de. Ideologia e Raízes Sociais do Clero da Conjuração. Viçosa (MG), Imprensa Universitária, 1978.

CASTRO, Martinho de Mello. "Instrução para o Visconde de Barbacena Luiz Antonio Furtado de Mendonça, Governador e Capitão General da Capitania de Minas Gerais”. Anuário do Museu da Inconfidência, 2, 1953, p.117-219.

COELHO, José João Teixeira. Instrução para o Governo da Capitania de Minas Gerais. Belo Horizonte, Fundação João Pinheiro; Centro de Estudos Históricos e Culturais, 1994 (Coleção Mineiriana. Série Clássicos).
COUTO, Soter. “O Inconfidente Rolim”. Revisto do Instituto Histórico e Geográfico de Minas Gerais, 10, 1963, p. 323-337.

ENNES, Ernesto. "Autos Crimes Contra os Réus Eclesiásticos da Conspiração de Minas Geraes". Anuário do Museu da Inconfidência, 1, 1952, p.9-69.

FARIA, Ana Mouta. "Função da Carreira Eclesiástica na Organização do Tecido Social do Antigo Regime". Ler História, 11, 1987, p. 29-46.

FRIEIRO, Eduardo. O Diabo na Livraria do Cônego. $2^{\text {a }}$ edição. São Paulo, EDUSP; Belo Horizonte, Itatiaia, 1981. (Reconquista do Brasil, nova série, 56)

GONZAGA, Tomás Antônio. Marília de Dirceu. (Org. de M. Cavalcanti Proença. Rio de Janeiro, Ediouro, s.d. (Prestígio).

GONZAGA, Tomás Antônio. Cartas Chilenas. Organização de Joaci Pereira Furtado. São Paulo, Companhia das Letras, 1995. (Retratos do Brasil, 1)

HESPANHA, António Manuel \& GOUVEIA, António Camões. "A Igreja”, in: MATTOSO, José (dir.). História de Portugal. Volume 4: O Antigo Regime (1620-1807). Lisboa (POR), Estampa, s.d., p. 287-299.

HESPANHA, António Manuel. "A Punição e a Graça", in: MATTOSO, José (dir.). História de Portugal. Volume 4: O Antigo Regime (1620-1807). Lisboa (POR), Estampa, s.d., p. 239-271.

HOORNAERT, Eduardo (coord.). História da Igreja no Brasil. Ensaio de Interpretação a Partir do Povo. Tomo II: Primeira Época. $4^{\mathrm{a}}$ ed. São Paulo, Paulinas; Petrópolis (RJ), Vozes, 1992. (História Geral da Igreja na América Latina)

IGLÉSIAS, Francisco. "Raízes Ideológicas da Inconfidência Mi- 
neira". Acervo, 4, 1, jan-jun de 1989, p.7-13.

JARDIM, Márcio. A Inconfidência Mineira: uma Síntese Factual. Rio de Janeiro, Biblioteca do Exército, 1989. (Biblioteca do Exército, 579; Coleção General Benício, 268)

LACOMBE, Américo Jacobina. "A Igreja no Brasil Colonial”, in: HOLANDA, Sérgio Buarque de (org.). História Geral da Civilização Brasileira. Tomo I, Volume II: Administração, Economia e Sociedade. São Paulo, Difel, 1960, p.51-75.

LEITE, Paulo Gomes. "A Inconfidência Mineira e a Ideologia Política do Iluminismo". Revista Minas Gerais, 19 ago.1989, p.6-9; 20 set-out.1989, p.6-9.

LUZ, Nícia Vilela. "Inquietações Revolucionárias no Sul: Conjuração Mineira", in HOLANDA, Sérgio Buarque de (org.) História Geral da Civilização Brasileira. Tomo I, Volume II: Administração, Economia e Sociedade. São Paulo, Difel, 1960, p. 394-405.

MACHADO FILHO, Aires da Mata. "O Padre Rolim e a Inconfidência Mineira no Tejuco". Revista do Brasil, $3^{\text {a }}$ fase, ano 3, 24, 1940, p.14-16.

MAXWELL, Kenneth. A Devassa da Devassa. A Inconfidência Mineira: Brasil e Portugal, 1750-1808. Traduzido por João Maia. $2^{a}$ ed. Rio de Janeiro, Paz e Terra, 1978. (Estudos Brasileiros, 22)

OLIVEIRA, Dom Oscar de. Os Dízimos Eclesiásticos no Brasil nos Períodos da Colônia e do Império. Belo Horizonte, Universidade de Minas Gerais, 1964. (Estudos, 3)

RAYNAL, Guilherme-Thomas François. A Revolução da Améri- ca. Traduzido por Regina Clara Simões Lopes. Rio de Janeiro, Arquivo Nacional, 1993. (Publicações Históricas, 91)

SALLES, Fritz Teixeira de. Vila Rica do Pilar. São Paulo, EDUSP; Belo Horizonte, Itatiaia, 1982. (Reconquista do Brasil, nova série, 71)

SANTOS, Joaquim Felício dos. Memórias do Distrito Diamantino da Comarca do Serro Frio. $4^{\mathrm{a}}$ ed. São Paulo, EDUSP; Belo Horizonte, Itatiaia, 1976. (Reconquista do Brasil, 26)

SANTOS, Lúcio José dos. A Inconfidência Mineira. Papel de Tiradentes na Inconfidência Mineira. São Paulo, Escolas Profissionais do Lyceu Coração de Jesus, 1927.

SOUZA, Laura de Mello e. Opulência e Miséria das Minas Gerais. $6^{a}$ ed. São Paulo, Brasiliense, 1994. (Tudo é História, 28).

TRINDADE, Raimundo. Arquidiocese de Mariana. Subsídios Para Sua História. $2^{\mathrm{a}}$ ed. Belo Horizonte, Imprensa Oficial, 1953. 2 volumes.

VASCONCELLOS, Diogo de. História do Bispado de Marianna. Belo Horizonte, Bibliotheca Mineira de Cultura, 1935.

VERSIANI, Carlos. Cultura e Autonomia em Minas Gerais (17681788): a Construção do Ideário Não-Colonial. Dissertação de Mestrado. São Paulo, FFLCH/USP, 1996.

VILLALTA, Luiz Carlos. "A 'América', a Ilustração e os Inconfidentes Mineiros: Apontamentos de Pesquisa". Registro, ano 2, 4, set.95-fev.96, p.15-17.

WEHLING, Arno. Administração Portuguesa no Brasil de Pombal a D. João (1777-1808). Brasília, FUNCEP, 1986. 